\title{
PENGARUH CURRENT RATIO, DEBT TO EQUITY RATIO DAN NET PROFIT MARGIN TERHADAP EARNING GROWTH PADA PERUSAHAAN PERTAMBANGAN YANG TERCATAT DI BURSA EFEK INDONESIA
}

\author{
Zulkifli \\ Fakultas Ekonomi dan Bisnis Universitas Mercu Buana \\ Email: zulkifli@mercubuana.ac.id
}

\begin{abstract}
This study aims to examine and analyze the effect of internal earning growth, annual data observation period 2012 until 2015. Type studies quantitative research. The population of all mining companies listed on the Indonesia Stock Exchange and consistently for four years amounted to 26 companies, with non-probability sampling technique is purposive sampling. Analysis data with panel data regression pooled the least square which has value adjusted r-squared $47.8 \%$ compared to other models. The results showed that current ratio (CR), debt to equity ratio (DER) and net profit margin (NPM) simultaneously are having the significant influence on the earnings growth. Partially, two variables are the current ratio, debt to equity ratio does not affect earnings growth. Meanwhile, NPM has a negative and significant effect on earning growth. Suggested adding variables external factors, using a sample of companies with other industries.
\end{abstract}

Keywords: current ratio, debt to equity ratio, net profit margin and earning growth

\begin{abstract}
Abstrak: Penelitian ini bertujuan untuk menguji dan menganalisis pengaruh pertumbuhan laba internal, observasi data tahunan periode 2012 hingga 2015. Jenis penelitian kuantitatif penelitian. Populasi semua perusahaan pertambangan yang terdaftar di Bursa Efek Indonesia dan secara konsisten selama empat tahun berjumlah 26 perusahaan, dengan teknik non-probability sampling adalah purposive sampling. Analisis data dengan regresi data panel mengumpulkan kuadrat terkecil yang memiliki nilai adjusted r-squared 47,8\% dibandingkan model lainnya. Hasil penelitian menunjukkan bahwa current ratio (CR), debt to equity ratio (DER) dan net profit margin (NPM) secara bersamaan memiliki pengaruh signifikan terhadap pertumbuhan laba. Secara parsial, dua variabel adalah rasio lancar, rasio utang terhadap ekuitas tidak mempengaruhi pertumbuhan laba. Sementara itu, NPM memiliki pengaruh negatif dan signifikan terhadap pertumbuhan laba. Disarankan menambahkan variabel faktor eksternal, menggunakan sampel perusahaan dengan industri lain.
\end{abstract}

Kata Kunci: current ratio, debt to equity ratio, net profit margin and earning growth

\section{PENDAHULUAN}

Perusahaan yang terdaftar di Bursa Efek Indonesia (BEI) memiliki tujuan yang berbeda dalam meningkatkan bisnis tata kelola perusahaan yaitu struktur modal dan citra merek. Penggunaan peningkatan bisnis umumnya dilakukan secara berkelanjutan. Keberadaan pasar modal dapat memberikan kemudahan memperoleh modal, operasional dan investasi (Groh \& Wallmeroth, 2016). Namun, tidak sedikit perusahaan yang perlu mengubah citra perusahaan menjadi lebih baik (Schaltegger \& Wagner, 2017). 
Produk-produk saham yang dikembangkan oleh BEI disajikan kepada investor sebagai solusi alternatif (Sadalia, Rahamani, \& Muda, 2017). Oleh karena itu, informasi dan pengetahuan analitis dalam memperoleh stok diperlukan, baik secara teknis dan fundamental. Penelitian ini dilakukan dengan maksud untuk mendeskripsikan keputusan dalam memilih kelayakan suatu saham sektor pertambangan. Tujuannya adalah agar investor mendapatkan manfaat optimal dan risiko kerugian minimal.

Dalam studi sebelumnya, terdapat pernyataan bahwa teknologi merupakan stimulus bagi pertumbuhan ekonomi (Leigh \& Blakely, 2016) dan mendukung produksi yang efektif dan efisien (Coe \& Helpman, 1995; Keller, 1998; Mayer \& Mayer, 2001; Teixeira $\&$ Fortuna, 2010). Pentingnya peningkatan kapasitas produksi bagi perusahaan pertambangan menyebabkan bahwa mereka wajib meningkatkan teknologi yang dimilikinya. Selain daripada itu, salah satu pandangan investor dalam melakukan prediksi adalah melalui analisis laporan keuangan dan manajemen pengelolaannya (Brigham \& Joel, 2006). Dalam analisis manajemen, laporan keuangan sangat bermanfaat dalam mengantisipasi prediksi dimasa depan sebagai titik awal perencanaan peningkatan kinerja perusahaan. Sebagaimana hasil penelitian Romanda, (2014) yang menyatakan bahwa apabila perusahaan mengumumkan laba tahunan dan hasil laba aktual lebih besar daripada dengan hasil prediksi laba yang dibuat, ini merupakan good news. Sebaliknya, jika prediksi laba tidak sesuai, maka yang terjadi adalah bad news. Oleh karena banyaknya variabel yang dapat mempengaruhi kemampuan suatu prediksi laba atas perusahaan, maka penelitian berkenaan predikti laba perusahaan ini masih diperlukan (Riahi, 2011).

Dalam penelitian ini kami mencoba menggambarkan earning growth sebagai berikut:

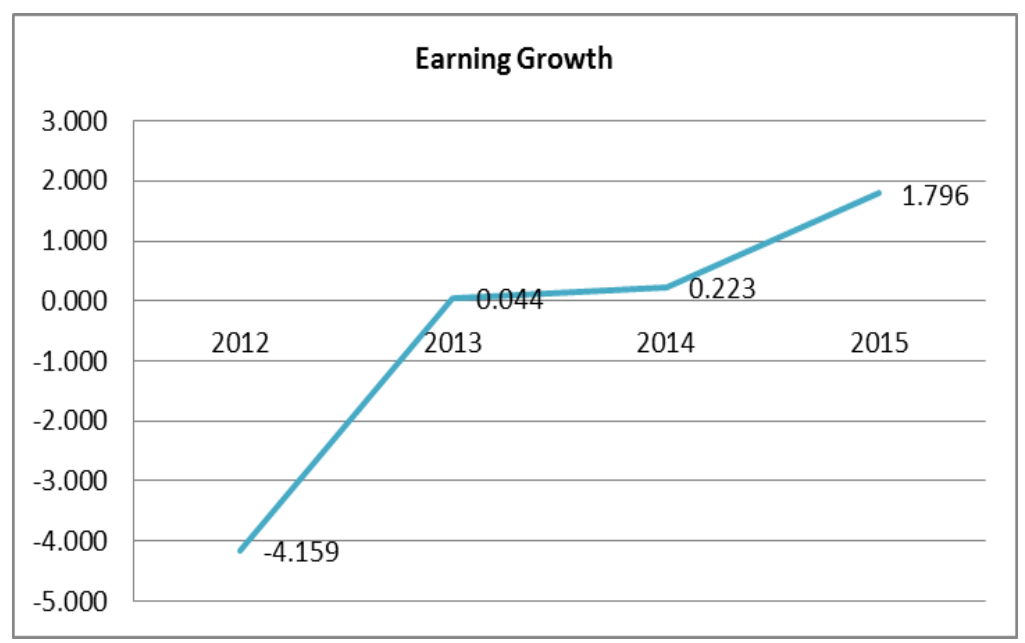

Gambar 1. Earning Growth

Berdasarkan Gambar 1, menunjukkan nilai rata-rata earning growth tahun 2012 memiliki nilai minimum $-4,159(-415.9 \%)$. Hal ini dapat diamati bahwa laba tahun sebelumnya 2011 lebih tinggi dibandingkan tahun 2012 sehingga mengalami penurunan laba. Namun jika diketahui dari current ratio memiliki nilai rasio sebesar 2.446 (244.6\%), net profit margin sebesar $0.146(14.6 \%)$ dan debt to equity ratio cukup tinggi sebesar 2.106 (210.6\%) pada tahun 2012 yang mencerminkan total kewajiban lebih tinggi dibandingkan ekuitas. Sedangkan tahun 2015 mengalami kenaikan laba sebesar 1.796 (179.6\%), current ratio sebesar 3.080 (308\%), net profit margin turun sebesar $-1.039(103.9 \%)$ dan dan debt 
to equity ratio sebesar $1.418(141.8 \%)$ yang mencerminkan total kewajiban lebih rendah dibandingkan ekuitas. Oleh karenanya dapat dianalisis untuk tahun 2012 terdapat CR, NPM dan DER tinggi, justru terjadi penurunan laba. Sebaliknya jika CR, NPM dan DER rendah maka terjadi peningkatan laba. Kesenjangan laba ini masih belum diketahui maka perlu dianalisis lebih lanjut dengan dugaan sementara apakah kenaikan dan turunya laba dipengaruho oleh CR, NPM dan DER.

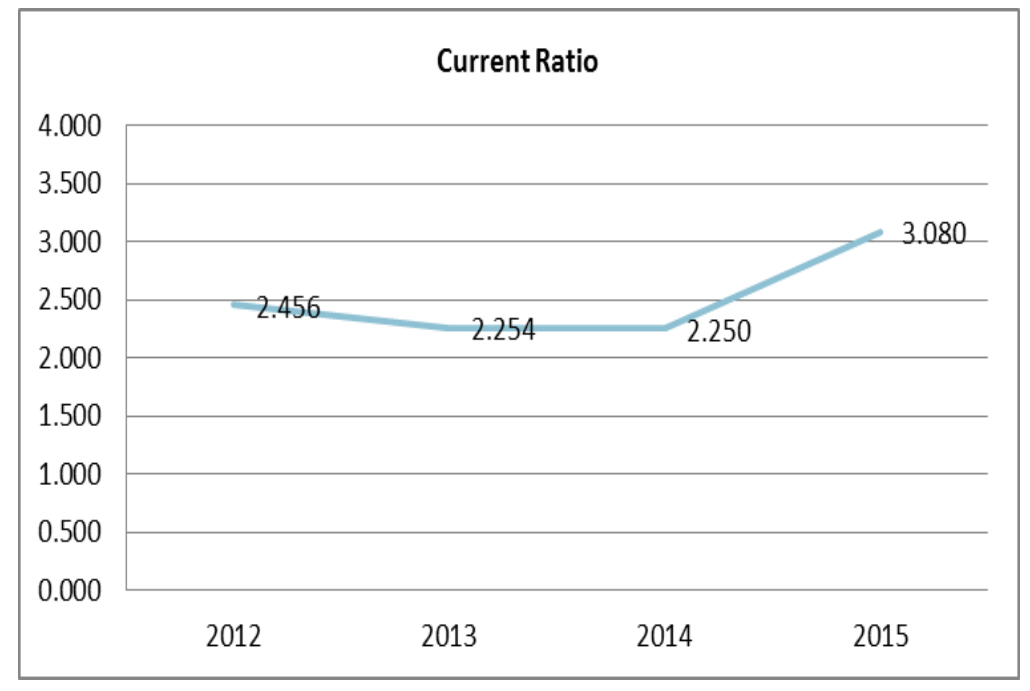

Gambar 2. Current Ratio

Berdasarkan Gambar 2, menunjukkan current ratio tahun 2014 memiliki nilai minimum 2.250 (225\%) dan tahun 2015 mencapai nilai maksimum 3.080 (308\%). Hal ini dapat diamati pada current ratio tahun 2014 bahwa utang lancar lebih tinggi dari pada aktiva lancar tahun 2014. Sedangkan tahun 2015 memiliki aktiva lancar lebih tinggi dari pada utang lancar. Tahun 2015 terjadi peningkatan disebabkan perusahaan lebih meningkatkan aktiva lancar kemungkinan disebabkan karena pengelolaan kas perusahaan lebih semakin baik dan meminimalkan utang lancarnya.

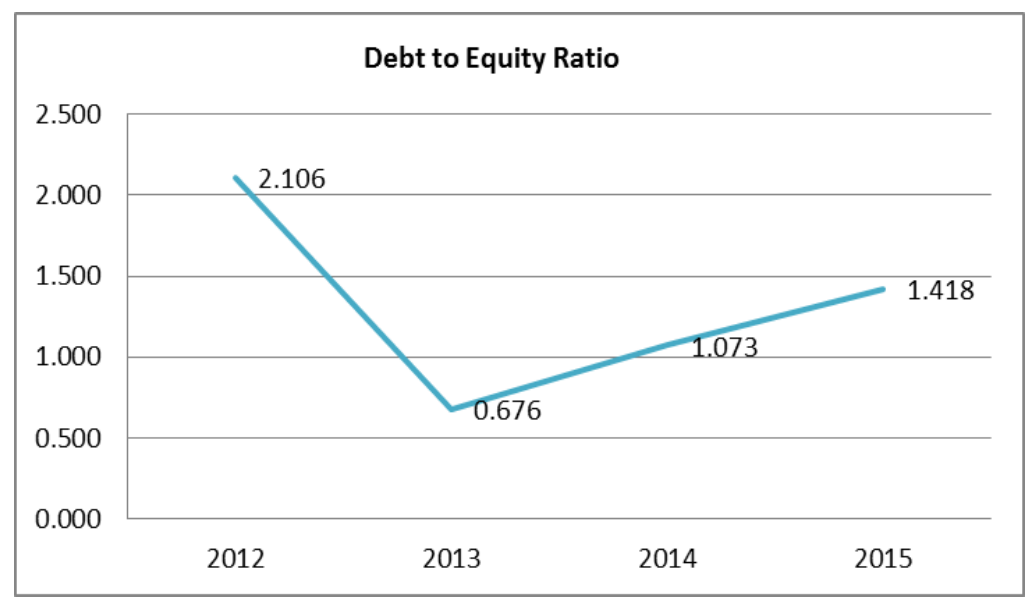

Gambar 3. Debt to Equity Ratio 
Berdasarkan Gambar 3, menunjukkan debt to equity ratio tahun 2013 memiliki nilai minimum 0.676 (67.6\%)dan tahun 2012 mencapai nilai maksimum 2.106 (210.6\%). Hal ini dapat diamati pada variabel debt to equity ratio tahun 2013 bahwa ekuitas lebih tinggi dari pada total kewajiban tahun 2013. Sedangkan tahun 2012 memiliki total kewajiban lebih tinggi dari pada ekuitas. Tahun 2015 terjadi peningkatan DER disebabkan karena kemampuan pengelolaan ekuitas yang kurang baik lebih diutamakan perusahaan meningkatkan utang perusahaan.

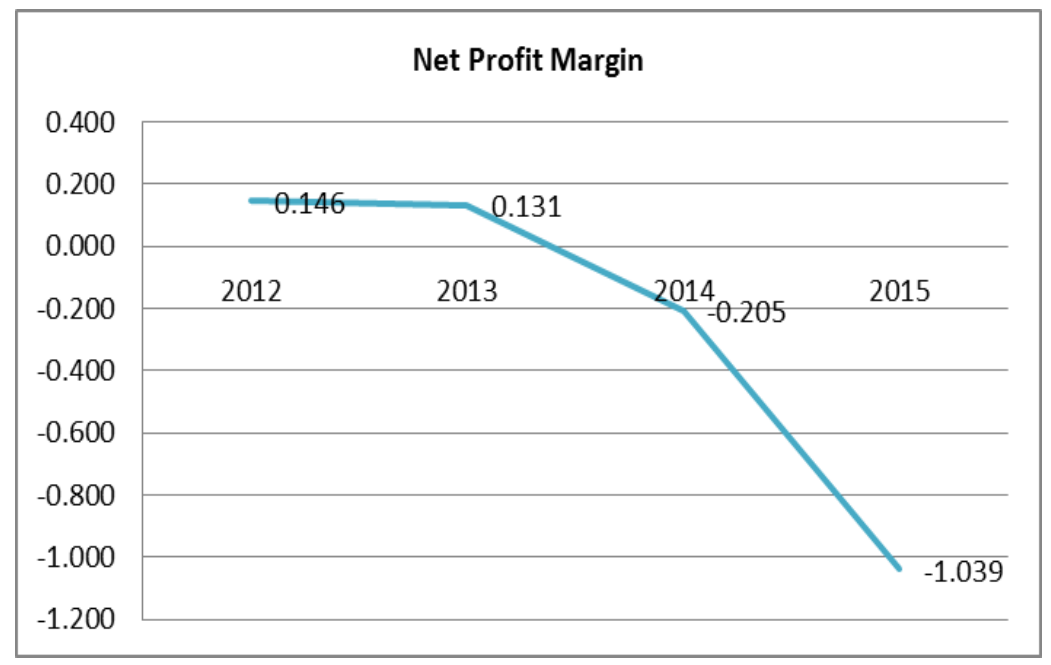

Gambar 4. Net Profit Margin

Berdasarkan Gambar 4, menunjukkan net profit margin tahun 2015 memiliki nilai minimum -1.039 (103.9\%) dan tahun 2012 mencapai nilai maksimum 0.146 (14.6\%). Hal ini dapat diamati pada variabel net profit margin tahun 2012 bahwa penjualan lebih tinggi dari pada laba tahun 2015. Sedangkan tahun 2012 memiliki laba lebih tinggi dari penjualan. Tahun 2015 disebabkan karena kemampuan pengelolaan keuangan yang kurang baik dari penjualan yang diperoleh perusahaan tidak dapat meningkatkan laba, justru kemungkinan cost (biaya) yang tinggi dikeluarkan perusahaan.

(Kurniawan, 2017) yang mengkaji analisis rasio keuangan untuk memprediksi pertumbuhan laba perusahaan manufaktur yang terdaftar di Bursa Efek Indonesia mendapatkan hasil penelitian untuk variabel working capital to total assets, current liabilities to equity, total asset turnover dan net profit margin tidak berpengaruh signifikan. Sedangkan operating income to total liabilities dan gross profit margin berpengaruh positif dan signifikan terhadap pertumbuhan laba.

Puspasari, Suseno, dan Sriwidodo, (2017) mengkaji pengaruh current ratio, debt to equity ratio, total asset turnover, net profit margin dan ukuran perusahaan terhadap pertumbuhan laba di perusahaan manufaktur subsektor farmasi yang terdaftar di BEI mendapatkan hasil penelitian untuk variabel current ratio tidak berpengaruh signifikan. Sedangkan debt to equity ratio dan total asset turnover berpengaruh negatif dan signifikan, namun net profit margin dan size berpengaruh positif dan signifikan terhadap pertumbuhan laba.

Lestari dan Suryono, (2017) mengkaji pengaruh profitabilitas dan aktivitas terhadap pertumbuhan laba pada perusahaan retail mendapatkan hasil penelitian untuk variabel 
return on assets, return on equity, net profit margin, operating profit margin dan inventory turnover secara parsial berpengaruh positif dan signifikan terhadap pertumbuhan laba. Wibisono \& Triyonowati, (2016) mengkaji pengaruh kinerja keuangan terhadap pertumbuhan laba pada perusahaan otomotif di BEI mendapatkan hasil penelitian untuk variabel quick ratio tidak berpengaruh signifikan. Sedangkan current ratio, debt to asset ratio dan total asset turnover berpengaruh positif dan signifikan, namun debt to equity ratio, inventory turnover, net profit margin dan gross profit margin berpengaruh negatif dan signifikan terhadap pertumbuhan laba.

Harnovinsah dan Marlita, (2017) mengkaji faktor-faktor yang mempengaruhi ekspektasi laba masa depan pada perusahaan food and beverages yang terdaftar di BEI mendapatkan hasil penelitian untuk variabel leverage mempunyai pengaruh positif dan signifikan terhadap ekspektasi laba.

Berdasarkan data perkembangan earning growth dan fenomena yang diuraikan di atas dan beberapa kesenjangan hasil penelitian terdahulu (research gap), maka penelitian ini perlu dilakukan untuk menelaah kembali dengan judul pengaruh current ratio, debt to equity ratio dan net profit margin terhadap pertumbuhan laba pada perusahaan pertambangan yang tercatat di Bursa Efek Indonesia periode 2012-2015.

Penelitian ini diharapkan dapat digunakan sebagai masukan dan bahan pertimbangan dalam menganalisis pertumbuhan laba perusahaan bagi investor untuk mengambil keputusan investasi dan bagi perusahaan untuk meningkatkan kinerja keuangan di masa yang akan datang serta untuk pihak teoritis sebagai sumber informasi dan referensi untuk penelitian selanjutnya untuk mendapat gambaran empiris tentang rasio keuangan terhadap earning growth sehingga memungkinkan untuk melanjutkan topik penelitian selanjutnya baik menambah variabel maupun perusahaan yang akan dianalisis.

Masalah dalam penelitian ini adalah: (1) Apakah terdapat pengaruh current ratio terhadap earning growth perusahaan pertambangan yang tercatat di Bursa Efek Indonesia periode 2012-2015?; (2) Apakah terdapat pengaruh debt to equity ratio terhadap earning growth perusahaan pertambangan yang tercatat di Bursa Efek Indonesia periode 20122015?; (3) Apakah terdapat pengaruh net profit margin terhadap earning growth perusahaan pertambangan yang tercatat di Bursa Efek Indonesia periode 2012-2015?

Tujuan penelitian adalah: (1) Untuk membuktikan secara empiris pengaruh current ratio terhadap earning growth perusahaan pertambangan yang tercatat di Bursa Efek Indonesia periode 2012-2015; (2) Untuk membuktikan secara empiris pengaruh debt to equity ratio terhadap earning growth perusahaan pertambangan yang tercatat di Bursa Efek Indonesia periode 2012-2015; (3) Untuk membuktikan secara empiris pengaruh net profit margin terhadap earning growth perusahaan pertambangan yang tercatat di Bursa Efek Indonesia periode 2012-2015.

\section{KAJIAN TEORI}

Signalling theory menjelaskan bahwa laporan keuangan yang baik merupakan sinyal atau tanda bahwa perusahaan juga telah beroperasi dengan baik (Jensen \& Meckling, 1976). Manajer berkewajiban memberikan sinyal mengenai kondisi perusahaan kepada pemilik sebagai wujud dari tanggung jawab atas pengelolaan perusahaan. Teori sinyal menjelaskan mengapa perusahaan mempunyai dorongan untuk memberikan informasi laporan keuangan kepada pihak eksternal. Dorongan perusahaan untuk memberikan informasi adalah karena terdapat asimetri informasi antara perusahaan dan pihak luar karena 
perusahaan mengetahui lebih banyak mengenai perusahaan dan prospek yang akan datang daripada pihak luar (Eliyani \& Utami, 2016; Ross, 1977; Utami \& Suharmadi, 1998). Zulkifli, Doktoralina, Marsyaf, \& Nurhasanah, 2018 yang mengkaji determining shares' internal return: fifty leading large-cap companies mendapatkan hasil penelitian untuk variabel debt to equity ratio berpengaruh positif dan signifikan terhadap return saham pada perusahaan yang memiliki nilai kapitalisasi tercatat di Bursa Efek Indonesia (BEI) dalam temuan empirisnya yaitu kenaikan debt to equity ratio disebabkan sebagian besar meningkatnya utang perusahaan dibandingkan dengan modalnya sehingga perusahaan dengan utang yang besar, mampu mendapatkan pinjaman dengan mudah yang memberikan kepercayaan kreditor/bank bahwa dengan utang yang besar dapat mengelola operasional perusahaan yang menghasilkan laba lebih besar.

Haningsih, Zulkifli, \& Doktoralina, 2014 yang mengkaji pengaruh total asset turn over, return on asset dan return on equity terhadap accumulation distribution line mendapatkan hasil penelitian untuk total asset turn over, return on asset berpengaruh positif dan signifikan terhadap accumulation distribution line pada perusahaan semen yang terdaftar Bursa Efek Indonesia (BEI) periode 2003 - 2014 dalam temuan empirisnya yaitu analisis teknikal accumulation distribution line membutuhkan harga saham sebagai indikator untuk mengkonfirmasi kekuatan (strength) dan kestabilan dibalik trend pergerakan harga dan volume yang mampu mengindentifikasi kenaikan atau penurunan volume transaksi pada suatu saham. Hal ini yang mempengaruhi harga dan volume perdagangan saham adalah laporan keuangan audit tahunan yang dianalisis rasionya sehingga mencerminkan kondisi perkembangan perusahaan pada profitabilitas untuk melangsungkan hidupnya harus dalam keadaan menguntungkan/profitable.

Darsono dan Purwanti (2008) menyatakan "Laba ialah prestasi seluruh karyawan dalam suatu perusahaan yang dinyatakan dalam bentuk angka keuangan yaitu selisih positif antara pendapatan dikurangi beban (Expenses)". Laba merupakan dasar ukuran kinerja bagi kemampuan manajemen dalam mengoperasikan harta perusahaan. Laba harus direncanakan dengan baik agar manajemen dapat mencapainya secara efektif.

Subramanyam \& Wild, (2010) menyatakan bahwa laba (earning) atau laba bersih (net income) mengindikasikan profitabilitas perusahaan. Laba mencerminkan pengembalian kepada pemegang ekuitas untuk periode yang bersangkutan. Laba merupakan perkiraan atas kenaikan atau penurunan ekuitas sebelum distribusi kepada dan kontribusi dari pemegang ekuitas. Semakin tinggi tingkat pertumbuhan perusahaan, akan semakin besar tingkat kebutuhan dana untuk membiayai ekspansi. Earning growth menurut Harahap (2001), sebagai berikut:

$$
\mathrm{EG}=\frac{\text { Laba bersih }(t)-\text { Laba bersih }(-t)}{\text { Laba bersih }(-t)} \times 100 \%
$$

Rasio lancar (current ratio) dinyatakan "Semakin tinggi current ratio ini berarti semakin besar kemampuan perusahaan untuk memenuhi kewajiban financial jangka pendek. Aktiva lancar yang dimaksud termasuk kas, piutang, surat berharga, dan persediaan. Dari aktiva lancar tersebut, persediaan merupakan aktiva lancar yang kurang likuid dibanding dengan yang lain. Akan tetapi bila current ratio terlalu tinggi ini akan berpengaruh negatif terhadap kemampuan laba karena sebagian modal kerjanya tidak berputar (Sumarsan, 2013). 
Current Ratio digunakan untuk mengukur kemampuan perusahaan untuk membayar hutang lancar yang dimiliki. Semakin tinggi Current Ratio ini semakin besar kemampuan perusahaan untuk memenuhi kewajiban finansial jangka pendek Sumarsan, (2013). Current ratio menurut Harahap, (2001) diukur, sebagai berikut:

$$
\mathrm{CR}=\frac{\text { Current Assets }}{\text { Current Liabilities }} \mathrm{X} 100 \%
$$

Debt to equity ratio menggambarkan sampai sejauh mana modal pemilik dapat menutupi utang-utang kepada pihak luar. Semakin kecil rasio ini semakin baik. Rasio ini disebut juga rasio leverage. Untuk keamanan pihak luar rasio terbaik jika modal lebih besar dari jumlah utang atau minimal sama. Namun bagi pemegang saham atau manajemen rasio leverage ini sebaiknya besar (Harahap, 2001). Peningkatan debt to equity ratio memperlihatkan besarnya kebutuhan dana yang diperlukan perusahaan untuk melakukan berbagai kegiatan perusahaan. Debt to equity ratio menurut (Harahap, 2001) diukur, sebagai berikut:

$$
\mathrm{DER}=\frac{\text { Total Utang }}{\text { Modal (equity) }} \times 100 \%
$$

Net profit margin termasuk salah satu rasio profitabilitas. Net profit margin menunjukkan kemampuan perusahaan dalam menghasilkan pendapatan bersihnya terhadap total penjualan bersihnya (Horne, 2009). Net profit margin yang semakin besar menunjukkan bahwa semakin besar laba bersih yang diperoleh perusahaan dari kegiatan penjualan. Dengan laba bersih yang besar, bertambah luas kesempatan bagi perusahaan untuk memperbesar modal usahanya tanpa melalui utang-utang baru, sehingga pendapatan yang diperoleh menjadi meningkat. Net profit margin menurut (Harahap, 2001) diukur, sebagai berikut:

$$
\mathrm{NPM}=\frac{\text { Pendapatan Bersih }}{\text { Penjualan }} \quad \text { X } 100 \%
$$

Heikal, Khaddafi dan Ummah (2014) menyatakan bahwa current ratio berpengaruh signifikan terhadap partumbuhan laba. Selaras dengan penelitian Wibisono \& Triyonowati, (2016) yang mendapatkan hasil penelitian untuk variabel current ratio berpengaruh positif dan signifikan terhadap pertumbuhan laba.

$\mathbf{H}_{1}$ : diduga terdapat pengaruh positif current ratio terhadap earning growth.

Debt Equity Ratio (DER) yang tinggi akan membebankan perusahaan pada biaya bunga yang tinggi. Tingginya biaya bunga yang harus dibayar oleh perusahaan akan berdampak pada penurunan laba perusahaan. Sebaliknya, DER yang rendah berarti biaya bunga yang dibayarkan oleh perusahaan juga rendah sehingga laba perusahaan akan meningkat yang akan berpengaruh pada pertumbuhan laba perusahaan (Zanora, 2013). Selaras dengan penelitian Puspasari et al., (2017) yang mendapatkan hasil penelitian untuk variabel debt to equity ratio berpengaruh negatif dan signifikan terhadap pertumbuhan laba.

H2: diduga terdapat pengaruh negatif debt to equity ratio terhadap earning growth. 
Harahap (2001) menyatakan net profit margin yang semakin besar menunjukkan bahwa semakin besar laba bersih yang diperoleh perusahaan dari kegiatan penjualan. Dengan laba bersih yang besar, bertambah luas kesempatan bagi perusahaan untuk memperbesar modal usahanya tanpa melalui utang-utang baru, sehingga pendapatan yang diperoleh menjadi meningkat. Selaras dengan penelitian Lestari \& Suryono, (2017); Puspasari et al., (2017) yang mendapatkan hasil penelitian untuk variabel net profit margin berpengaruh positif dan signifikan terhadap pertumbuhan laba.

H3: diduga terdapat pengaruh positif net profit margin terhadap earning growth.

Penelitian ini menggambarkan rerangka pemikiran sebagai berikut:

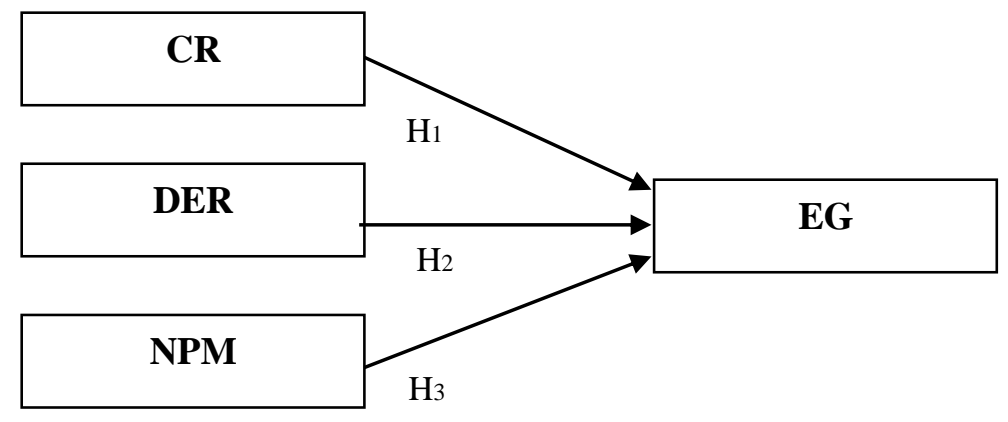

Gambar 2. Rerangka Pemikiran

\section{METODE}

Desain Penelitian. Penelitian menggunakan desain penelitian kausal untuk mengetahui pengaruh satu variabel atau lebih antara variabel bebas (independent variable) terhadap variabel terikat (dependent variable).

Variabel Operasional dan Skala Pengukuran. Penelitian ini menggunakan 2 (dua) macam variabel, yaitu variabel terikat (dependent variable) yaitu earning growth dan variabel bebas (independent variable) yaitu current ratio, debt to equity ratio dan net profit margin.

Tabel 1. Variabel Operasional dan Skala Pengukuran

\begin{tabular}{|c|c|c|c|c|c|}
\hline No & Variabel & Definisi Operasional & \multicolumn{3}{|c|}{ Pengukuran } \\
\hline \multirow[t]{2}{*}{1.} & \multirow[t]{2}{*}{$\begin{array}{l}\text { Dependen: } \\
\text { Earning growth }(\mathrm{Y})\end{array}$} & \multirow{2}{*}{$\begin{array}{l}\text { Laba bersih tahun ini } \\
\text { dikurangi dengan laba } \\
\text { bersih tahun lalu dan } \\
\text { dibagi laba bersih tahun } \\
\text { lalu }\end{array}$} & \multicolumn{3}{|c|}{ Laba bersih $(t)-$ Laba bersih $(-t)$} \\
\hline & & & \multicolumn{3}{|c|}{ Laba bersih $(-t)$} \\
\hline \multirow[t]{5}{*}{2.} & Independen: & \multirow{3}{*}{$\begin{array}{l}\text { Aktiva lancar dibagi } \\
\text { dengan kewajiban lancar }\end{array}$} & \multirow{3}{*}{$\mathrm{CR}=-$} & Gurrent Assets & \multirow{3}{*}{ X $100 \%$} \\
\hline & \multirow{2}{*}{ Current ratio $(\mathrm{X} 1)$} & & & 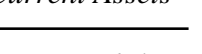 & \\
\hline & & & & Current Liabilities & \\
\hline & \multirow{2}{*}{ Debt to equity ratio $(\mathrm{X} 2)$} & \multirow{2}{*}{$\begin{array}{l}\text { Total kewajiban dibagi } \\
\text { dengan modal }\end{array}$} & \multirow{2}{*}{$\mathrm{DER}=$} & Total Utang & \multirow{2}{*}{ X $100 \%$} \\
\hline & & & & Modal & \\
\hline
\end{tabular}


Metode Pengumpulan Data. Teknik pengumpulan data yang digunakan adalah metode kepustakaan dengan cara membaca, mengamati, mencatat dan mempelajari dengan cara mengumpulkan data yang melalui sumber-sumber tertulis seperti uraian teori dalam bukubuku dan jurnal- jurnal, yang berhubungan dengan masalah yang diteliti serta mengunduh data dan informasi dari situs-situs internet yang relevan.

Populasi dan Sampel. Populasi penelitian adalah seluruh perusahaan pertambangan yang tercatat di Bursa Efek Indonesia (BEI) berjumlah 26 (dua puluh enam). Teknik pengambilan sampel dalam penelitian ini dengan purposive sampling. Teknik pengambilan sampel dalam penelitian ini dengan purposive sampling dalam teknik ini berdasarkan kreteria yang telah dirumuskan terlebih dahulu. Penelitian ini perusahaan yang memenuhi kriteria telah ditetapkan sebagai berikut: (1) Perusahaan yang tercatat di Bursa Efek Indonesia (BEI) secara konsisten selama periode penelitian berlangsung tetap tercatat dari periode 2012 - 2015; (2) Perusahaan yang masuk dalam sektor pertambangan dan mempublikasikan laporan keuangan selama periode pengamatan penelitian.

Teknik Analisis Data. Teknik analisis data yang digunakan dalam penelitian ini adalah analisis regresi data panel yang merupakan gabungan data time series dan cross section. Pendekatan dalam menganalisis regresi linear berganda dalam data panel menurut Gujarati (2006), diantaranya:

1. Pooled Least Square. Pendekatan yang paling sederhana dalam pengolahan data panel adalah dengan menggunakan metode kuadrat terkecil biasa atau sering disebut Pooled Least Square (PLS) yang diterapkan dalam data yang berbentuk pool.

2. Fixed Effect. Pendekatan metode kuadrat terkecil adalah adanya asumsi intersep dan slope dari persamaan regresi yang dianggap konstan, baik antar daerah maupun antar waktu yang kurang sesuai dengan tujuan penggunaan data panel. Untuk mengatasi hal ini kita dapat menggunakan pendekatan model efek tetap (fixed effect).

3. Random Effect. Pendekatan ini perbedaan antar waktu dan antar individu diakomodasi melalui error. Error dalam pendekatan ini terbagi menjadi error untuk komponen individu dan error, error komponen waktu, error gabungan. Pendekatan ini menggunakan metode Generalized Least Square (GLS).

Pemilihan Model Data Panel sebagai berikut:

1. Uji Chow adalah pengujian yang dilakukan untuk mengetahui apakah model yang digunakan adalah pooled least square atau fixed effect. Jika nilai sig lebih kecil dari 0.05 , berarti fixed effect model yang lebih baik, kemudian akan dilanjutkan dengan uji Hausman. Sebaliknya jika nilai sig lebih besar dari 0.05 , maka pooled least square model yang lebih baik.

2. Uji Hausman adalah pengujian yang dilakukan untuk mengetahui apakah model yang digunakan adalah fixed effect atau random effect. Jika nilai sig lebih kecil dari 0.05 , berarti fixed effect model yang lebih baik. Sebaliknya jika nilai sig lebih besar dari 0.05 , maka random effect model yang lebih baik 
Uji Hipotesis yang dibentuk melalui pengujian sebagai berikut:

1. Uji Koefisien Determinasi yang dinotasikan dengan $R^{2}$ digunakan sebagai uji statistik inferensial untuk kebaikan dari kesesuaian model (goodness of fit) yang mengukur berapa persentase variasi menjelaskan besarnya pengaruh semua variabel bebas terhadap variabel terikat. $R^{2}$ memilih range antara $0 \leq R^{2} \leq 1$. Jika $R^{2}$ bernilai 1 , maka garis regresi menjelaskan $100 \%$ variasi dalam variabel terikat. Sebaliknya jika $R^{2}$ sama dengan 0 maka garis regresi tidak menjelaskan variasi dalam variabel terikat. Penelitian ini menggunakan adjusted $r$-squared.

2. Uji Signifikansi Simultan (F) dilakukan untuk melihat signifikansi pengaruh secara bersama- sama variabel independen dalam model terhadap variabel dependen. Jika nilai sig lebih kecil dari 0.05, berarti variabel independen secara bersama-sama berpengaruh terhadap variabel dependen. Sebaliknya nilai sig lebih besar dari 0.05 , berarti variabel independen secara bersama-sama tidak berpengaruh terhadap variabel dependen, maka model penelitian ini tidak layak digunakan dalam penelitian.

3. Uji Signifikansi Parsial (t) dilakukan dengan nilai statistik untuk melihat signifikansi pengaruh individu dari variabel independen dalam model regresi terhadap variabel dependen. Jika nilai sig lebih kecil dari 0.05 , berarti variabel independen secara individu berpengaruh terhadap variabel dependen. Sebaliknya nilai sig lebih besar dari 0.05 , berarti variabel independen secara individu tidak berpengaruh terhadap variabel dependen.

\section{HASIL DAN PEMBAHASAN}

Hasil Perhitungan Uji Masing- masing Model. Metode regresi data panel yang digunakan dalam penelitan ini didasarkan atas tiga model yaitu pooled least square, fixed effect dan random effect sehingga model yang paling terbaik dalam penelitian ini untuk dianalisis lebih lanjut, sebelum mengetahui hasil penelitian maka akan dilakukan uji berpasangan untuk masing-masing model dengan uji chow dan hausman.

Tabel 2. Hasil Uji Chow test

\begin{tabular}{lrrr}
\hline \hline Effects Test & Statistic & d.f. & Prob. \\
\hline \hline Cross-section F & 1.448948 & $(25,75)$ & 0.1118 \\
Cross-section Chi-square & 40.981761 & 25 & 0.0231 \\
\hline \hline
\end{tabular}

Sumber: Data diolah (2018)

Berdasarkan Tabel 2, menunjukkan nilai probabilitas $\mathrm{F}$ test 0.11 lebih besar dari $\alpha=0,05$, maka $\mathrm{H}_{0}$ diterima dan $\mathrm{H}_{\mathrm{a}}$ ditolak yang berarti bahwa model pooled least square yang lebih baik digunakan dalam mengestimasi regresi data panel dibandingkan model fixed effect sehingga tidak perlu dilanjutkan dengan pengujian hausman test untuk mengetahui apakah yang lebih tepat dengan model fixed effect atau random effect.

Estimasi Model Regresi Data Panel Secara Bersama-sama. Berdasarkan Tabel 3, menunjukkan uji goodness-of-fit yang diukur dengan Adjusted R-squared menunjukkan nilai sebesar $47.8 \%$, berarti variasi perubahan baik kenaikan maupun penurunan earning growth perusahaan dapat dijelaskan oleh current ratio, debt to equity ratio, net profit 
margin. Sedangkan sisanya dengan nilai sebesar 52.2\% telah dijelaskan oleh variabelvariabel lain yang tidak digunakan dalam model penelitian ini. Pengujian signifikansi secara bersama-sama menunjukkan nilai probabilitas 0.000 lebih kecil dari $\alpha=0.05$. Hal ini berarti $\mathrm{H}_{0}$ ditolak dan $\mathrm{H}_{\mathrm{a}}$ diterima sehingga dapat dinyatakan bahwa current ratio, debt to equity ratio, net profit margin secara bersama-sama memengaruhi earning growth berarti variabel independen yang diukur menentukan layak dimasukan kedalam model penelitian ini.

Tabel 3. Hasil Estimasi Model Regresi Data Panel

\begin{tabular}{|c|c|c|c|c|}
\hline \multicolumn{5}{|c|}{$\begin{array}{l}\text { Dependent Variable: EG? } \\
\text { Method: Pooled Least Squares } \\
\text { Date: 05/30/18 Time: 05:47 } \\
\text { Sample: } 2012 \text { 2015 } \\
\text { Included observations: } 4 \\
\text { Cross-sections included: } 26 \\
\text { Total pool (balanced) observations: } 104 \\
\text { Cross sections without valid observations dropped } \\
\text { Dependent Variable: EG? }\end{array}$} \\
\hline Variable & Coefficient & Std. Error & t-Statistic & Prob. \\
\hline $\mathrm{C}$ & -0.138296 & 0.232853 & -0.593922 & 0.5539 \\
\hline $\mathrm{CR}$ ? & -0.093699 & 0.078214 & -1.197977 & 0.2338 \\
\hline DER? & -0.026186 & 0.031568 & -0.829503 & 0.4088 \\
\hline NPM? & -1.628969 & 0.167075 & -9.749897 & 0.0000 \\
\hline R-squared & 0.493351 & \multirow{5}{*}{\multicolumn{2}{|c|}{$\begin{array}{l}\text { Mean dependent var } \\
\text { S.D. dependent var } \\
\text { Sum squared resid } \\
\text { Durbin-Watson stat }\end{array}$}} & -0.708323 \\
\hline Adjusted R-squared & 0.478152 & & & 12.07966 \\
\hline S.E. of regression & 8.641511 & & & 7467.571 \\
\hline F-statistic & 32.45846 & & & 1.878566 \\
\hline Prob(F-statistic) & 0.000000 & & & \\
\hline
\end{tabular}

Sumber: Data diolah (2018)

Estimasi Model Regresi Data Panel Secara Parsial. Berdasarkan hasil estimasi earning growth perusahaan pertambangan yang tercatat di Bursa Efek Indonesia (BEI) secara konsisten selama periode 2012- 2015 menggunakan model pooled least square yang lebih baik seperti yang ditunjukkan dalam Tabel 3, dalam bentuk persamaan sebagai berikut:

\section{EG = -0.138 C -0.093 CR -0.026 DER -1.628 NPM}

$\mathbf{C}_{\mathbf{i}}=$ konstanta pooled least square perusahaan ke-i, $\mathrm{i}=1, \ldots . .26$.

Berdasarkan persamaan yang diperoleh yaitu interprestasi untuk $C=-0.138$ adalah persamaan regresi data panel ini memiliki makna bahwa apabila tidak ada variabel independen, maka nilai earning growth sebesar -13.8 persen.

1. Pengaruh current ratio terhadap earning growth. Berdasarkan uji-t menunjukkan variabel current ratio dengan koefisien regresi sebesar $\beta_{1}=-0.093$ yang memengaruhi earning growth perusahaan pertambangan yang tercatat di Bursa Efek Indonesia (BEI) secara negatif dan current ratio tidak memengaruhi earning growth dengan tingkat keyakinan sebesar 95 persen, dimana nilai probabilitas t-statistic 0.233 lebih besar dari $\alpha$ $=0,05$ yang berarti hipotesis alternatif $(\mathrm{Ha})$ ditolak dan hipotesis nol $(\mathrm{Ho})$ diterima. 
2. Pengaruh debt to equity ratio terhadap earning growth. Berdasarkan uji-t menunjukkan variabel debt to equity ratio dengan koefisien regresi sebesar $\beta_{2}=-0.026$ yang memengaruhi earning growth perusahaan pertambangan yang tercatat di Bursa Efek Indonesia (BEI) secara negatif dan debt to equity ratio tidak memengaruhi earning growth dengan tingkat keyakinan sebesar 95 persen, dimana nilai probabilitas t-statistic 0.408 lebih besar dari $\alpha=0,05$ yang berarti hipotesis alternatif (Ha) ditolak dan hipotesis nol (Ho) diterima.

3. Pengaruh net profit margin terhadap earning growth. Berdasarkan uji-t menunjukkan variabel net profit margin dengan koefisien regresi sebesar $\beta_{3}=-1.628$ yang memengaruhi earning growth perusahaan pertambangan yang tercatat di Bursa Efek Indonesia (BEI) secara negatif dan net profit margin memengaruhi signifikan terhadap earning growth dengan tingkat keyakinan sebesar 95 persen, dimana nilai probabilitas tstatistic 0.000 lebih kecil dari $\alpha=0,05$ yang berarti hipotesis alternatif (Ha) diterima dan hipotesis nol (Ho) ditolak. Interprestasi untuk $\beta_{3}=-1.628$ adalah jika terjadi kenaikan net profit margin sebesar 1 persen, dengan asumsi variabel lain tidak mengalami perubahan (ceteris paribus), maka earning growth perusahaan akan mengalami penurunan laba sebesar -1.628 persen.

\section{Pembahasan}

1. Pengaruh current ratio terhadap earning growth. Current ratio tidak memengaruhi earning growth perusahaan. Hasil empiris ini tidak konsisten dengan hasil penelitian Heikal, Khaddafi dan Ummah (2014), Wibisono dan Triyonowati (2016) menyatakan bahwa current ratio berpengaruh positif dan signifikan terhadap earning growth. Namun terdapat hasil empiris yang selaras dinyatakan oleh Puspasari et al (2017) bahwa tidak memengaruhi earning growth. Temuan empiris ini berarti kenaikan current ratio kemungkinan disebabkan sebagian besar perusahaan meningkatnya jumlah kas, banyak atau sedikitnya dana yang dialokasi pada kas, persediaan, piutang dan kewajiban jangka pendek tidak berdampak pada kenaikan atau penurunan penjualan/pendapatan untuk memperoleh laba.

2. Pengaruh debt to equity ratio terhadap earning growth. Debt to equity ratio tidak memengaruhi earning growth perusahaan. Hasil empiris ini tidak konsisten dengan hasil penelitian Wibisono dan Triyonowati (2016), Zanora (2013) dan Puspasari et al (2017) menyatakan bahwa debt to equity ratio berpengaruh negatif dan signifikan terhadap earning growth. Sebagaimana dalam hasil empiris ini juga sama halnya dengan hasil penelitian Harnovinsah dan Marlita (2014) yang mengkaji faktor-faktor yang mempengaruhi ekspektasi laba masa depan pada perusahaan food and beverages yang terdaftar di BEI mendapatkan hasil penelitian untuk variabel leverage mempunyai pengaruh positif dan signifikan terhadap ekspektasi laba. Temuan empiris ini berarti debt to equity ratio disebabkan kemungkinan sebagian besar perusahaan meningkat atau menurunnya debt to equity ratio tidak ada pengaruhnya dengan laba karena perusahaan untuk menghasilkan laba sumbernya dari penjualan/pendapatan. Tinggi dan rendahnya penjualan/pendapatan akan memengaruhi pertumbuhan laba, maka penggunaan utang dalam struktur modal tidak berdampak pada kenaikan atau penurunan tingkat pengembalian yang dihasilkan perusahaan.

3. Pengaruh net profit margin terhadap earning growth. Net profit margin memengaruhi earning growth perusahaan secara negatif dan signifikan. Hasil empiris ini tidak konsisten dengan hasil penelitian Puspasari et al (2017) dan Lestari dan 
Suryono (2016) menyatakan bahwa net profit margin berpengaruh positif dan signifikan terhadap earning growth. Temuan empiris ini berarti net profit margin kemungkinan disebabkan sebagian besar perusahaan meningkatnya laba seiring dengan meningkatnya penjualan /pendapatan perusahaan namun akan berdampak terhadap peningkatan biaya operasional yang memengaruhi turunnya laba.

\section{PENUTUP}

Simpulan. Penelitian ini melakukan analisis earning growth perusahaan pertambangan yang tercatat di Bursa Efek Indonesia (BEI) secara konsisten selama periode 2012- 2015. Analisis terhadap penelitian ini dengan menggunakan model pooled least squares yang lebih baik dengan menghasilkan nilai adjusted r-squared $47.8 \%$ dibandingkan dengan fixed effect dan random effect. Model penelitian ini untuk menganalisis earning growth menggunakan variabel independen yaitu current ratio, debt to equity ratio dan net profit margin. Secara lebih khusus, kesimpulan dari penelitian ini adalah:

1. Current ratio tidak memengaruhi earning growth perusahaan. Temuan empiris ini tidak sesuai dengan hipotesis penelitian yang menyatakan bahwa variabel current ratio berpengaruh positif dan signifikan terhadap earning growth.

2. Debt to equity ratio tidak memengaruhi earning growth perusahaan. Temuan empiris ini tidak sesuai dengan hipotesis penelitian yang menyatakan bahwa variabel debt to equity ratio berpengaruh negatif dan signifikan terhadap earning growth.

3. Net profit margin memengaruhi earning growth perusahaan secara negatif dan signifikan. Temuan empiris ini tidak sesuai dengan hipotesis penelitian yang menyatakan bahwa variabel net profit margin berpengaruh positif dan signifikan terhadap earning growth.

Saran. Berdasarkan keterbatasan penelitian, maka saran penelitian selanjutnya agar hasil empiris penelitian ini didukung oleh temuan-temuan yang lebih bervariasi, yaitu:

1. Penelitian selanjutnya disarankan untuk menambah variabel faktor internal kinerja keuangan lainnya karena temuan empiris ini menghasilkan nilai adjusted $r$-squared $47.8 \%$ yang berarti variabel current ratio, debt to equity ratio dan net profit margin yang digunakan dalam penelitian ini dapat memberikan kontribusi terhadap earning growth sebesar $47.8 \%$. Jika menambahkan atau menggunakan faktor-faktor lain yang memengaruhi earning growth tidak hanya pada faktor internal saja namun dapat juga menambahkan faktor-faktor eksternal perusahaan seperti suku bunga, inflasi, nilai tukar dan pertumbuhan ekonomi. Kemungkinan sisanya 52.2\% dapat dijelaskan dengan variabel independen lainnya yang memberikan kontribusi terhadap kenaikan adjusted $r$-squared yang dapat menghasilkan hasil penelitian yang lebih komprenshif.

2. Penelitian selanjutnya disarankan menggunakan sampel perusahaan bukan hanya pada perusahaan pertambangan namun pada industri lain untuk menambah sampel karena temuan empiris ini menghasilkan nilai earning growth. $47.8 \%$ yang berarti sampel perusahaan pertambangan dapat menjelaskan $47.8 \%$. Jika menggunakan sampel perusahaan pada seluruh perusahaan yang tercatat di Bursa Efek Indonesia, kemungkinan sisanya 52.2\% dapat menjelaskan variasi kenaikan adjusted $r$-squared sehingga dapat memberikan rekomendasi dan saran yang kuat bagi para pihak yang berkepentingan sehingga memberikan temuan baru untuk memperkuat dan menggeneralisasi hasil temuan sehingga menjadi acuan bagi investor serta para 
akademisi untuk mengetahui current ratio, debt to equity ratio dan net profit margin yang memengaruhi earning growth.

\section{DAFTAR RUJUKAN}

Brigham, E. F., \& Joel, H. F. (2006). Fundamentals of Financial Management (DasarDasar Manajemen Keuangan), Edisi Kesepuluh, alih bahasa; Ali Akbar Yulianto. Jakarta: Salemba Empat.

Coe, D. T., \& Helpman, E. (1995). International r\&d spillovers. European Economic Review, 39(5), 859-887.

Darsono, Purwanti Arif, (2008). Penganggaran Perusahaan. Mitra Wacana Media, Jakarta

Eliyani, L., \& Utami, W. (2016). A Study of Investor Response to New Product Launching: A Competitive Strategy Approach. Malaysian Accounting Review, 15(2).

Groh, A. P., \& Wallmeroth, J. (2016). Determinants of venture capital investments in emerging markets. Emerging Markets Review, 29, 104-132.

Heikal, Mohd, Muammar Khaddafi dan Ainatul Ummah. (2014). "Influence Analysis of Return on Assets (ROA), Return on Equity (ROE), Net Profit Margin (NPM), Debt to Equity Ratio (DER), and Current Ratio (CR), Against CorporateProfit Growth In Automotive In Indonesia Stock Exchange". International Journal of Academic Research in Business and Social Sciences, 4(12), 101-114

Haningsih, L., Zulkifli, Z., \& Doktoralina, C. M. (2014). "Pengaruh Total Asset Turn Over, Return on Asset dan Return on Equity terhadap Accumulation Distribution Line". Jurnal Akuntansi, 18(3), 438-458.

Harahap, S. S. (2001). Analisa kritis atas laporan keuangan. RajaGrafindo Persada.

Harnovinsah, H., \& Marlita, M. (2017). "Faktor-faktor yang mempengaruhi Ekspektasi Laba masa depan pada perusahaan Food and Beverges yang terdaftar di Bursa Efek Indonesia". Jurnal Sains Akuntansi Indonesia, 1(1), 21-37.

Jensen, M. C., \& Meckling, W. H. (1976). "Theory of the firm: Managerial behavior, agency costs and ownership structure". Journal of Financial Economics, 3(4), 305360.

Keller, W. (1998). "Are international R\&D spillovers trade-related?: Analyzing spillovers among randomly matched trade partners". European Economic Review, 42(8), 14691481.

Kurniawan, A. H. (2017). "Analisis Rasio Keuangan untuk Memprediksi Pertumbuhan Laba Perusahaan Manufaktur yag terdaftar di bursa Efek Indonesia". KINDAI Kumpulan Informasi Dan Artikel Ilmiah Manajemen Dan Akuntansi, 13(1).

Leigh, N. G., \& Blakely, E. J. (2016). Planning local economic development: Theory and practice. SAGE publications.

Lestari, N. D., \& Suryono, B. (2017). "Pengaruh Profitabilitas dan Aktivitas terhadap Pertumbuhan Laba pada Perusahaan Retail". Jurnal Ilmu Dan Riset Akuntansi, 5(11).

Mayer, J., \& Mayer, J. (2001). Technology diffusion, human capital and economic growth in developing countries.

Puspasari, M. F., Suseno, Y. D., \& Sriwidodo, U. (2017). Pengaruh Current Ratio, Debt to Equity Ratio, Debt to Equity Ratio, Total Asset Turnover, Net Profit Margin dan Ukuran Perusahaan terhadap Pertumbuhan Laba. Manajemen Sumber Daya Manusia, 11(1). 
Riahi, A. D. B. (2011). Accounting Theory Edisi 5. Salemba Empat. Jakarta Selatan.

Romanda, C. (2014). "Faktor--faktor Yang Mempengaruhi Sensitivitas Laba Pada Industri Barang Konsumsi Di Indonesia". Jurnal Manajemen Bisnis, 2(2).

Ross, L. D. (1977). Problems in the interpretation of" self-serving" asymmetries in causal attribution: Comments on the Stephan et al. paper. Sociometry, 112-114.

Sadalia, I., Rahamani, N. A. B., \& Muda, I. (2017). "The Significance of Internet Based Financial Information Disclosure on Corporates' Shares in Indonesia". International Journal of Economic Research, 14(12), 337-346.

Schaltegger, S., \& Wagner, M. (2017). Managing the business case for sustainability: The integration of social, environmental and economic performance. Routledge.

Subramanyam, K. R., \& Wild, J. J. (2010). Analisis Laporan Keuangan. Analisis Laporan Keuangan. Salemba Empat. Jakarta.

Sumarsan, T. (2013). Sistem Pengendalian Manajemen: Konsep, Aplikasi, dan Pengukuran Kinerja. PT. Indeks. Jakarta Barat.

Teixeira, A. A. C., \& Fortuna, N. (2010). "Human capital, R\&D, trade, and long-run productivity. Testing the technological absorption hypothesis for the Portuguese economy", 1960--2001. Research Policy, 39(3), 335-350.

Utami, W., \& Suharmadi, S. (1998). "Pengaruh Informasi Penghasilan Perusahaan terhadap Harga Saham di Bursa Efek Jakarta". The Indonesian Journal of Accounting Research, 1(2).

Wibisono, S. A., \& Triyonowati, T. (2017). "Pengaruh Kinerja Keuangan terhadap Pertumbuhan Laba pada Perusahaan Otomotif di BEI". Jurnal Ilmu \& Riset Manajemen, 5(12).

Zanora, V. (2013). "Pengaruh Likuditas, Leverage Dan Aktivitas Terhadap Pertumbuhan Laba (Studi Empiris pada Perusahaan Manufaktur yang Terdaftar di BEI Periode 2009-2011)". Jurnal Akuntansi, 1(3).

Zulkifli, Doktoralina, C., Marsyaf, \& Nurhasanah. (2018). "Determining Shares' Internal Return: Fifty Leading Large-Cap Companies". Research Journal of Finance and Accounting, 13(10). 